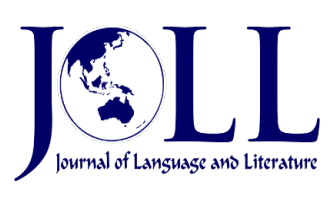

Vol. 21 No. 1, April 2021, pp. 198 - 211

DOI: 10.24071/joll.v21i1.2933

Available at https://e-journal.usd.ac.id/index.php/JOLL/index

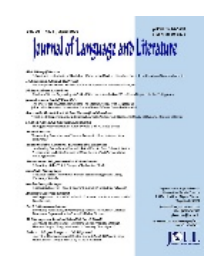

This work is licensed under a Creative Commons Attribution-ShareAlike 4.0 International License.

\title{
The Study of Reduplication and Retriplication in the Yoruba Language
}

\author{
Joseph Friday-Otun \\ friday.otun2016@gmail.com \\ Department of Linguistics and Nigerian Languages, University of Ilorin, NIGERIA
}

\begin{abstract}
The Yoruba language, a regional lingua franca in Nigeria, which belongs to the Kwa sub-family of Kordofanian phylum of the larger African language family, is spoken in Nigeria, Togo, Ghana, Liberia, Brazil, Cuba, etc. The language attests a very productive feature of reduplication which has attracted the attention of many scholars. But its extended form, tagged, "retriplication" in this paper, remains largely unexplored. This study examines the form and functions of reduplication and retriplication which are two morphological processes where the former serves as a pedestal to the latter. While applying the participant observation method to elicit data from main Yoruba cities in Nigeria, the Pulleyblank (2009) model, as well as the descriptive and context usage approaches are employed to analyse and discuss the data. The study reveals that while reduplication process actualises intensification, nominalisation, emphasis and comparative qualifying, retriplication serves for more intensification, wider nominalisation, more emphasis and superlative qualifying. The research further reveals that, while all cases of verb and adjective reduplicates can be retriplicated without generating unacceptable utterances in Yoruba, the gerundive reduplicates cannot culminate in retriplication. However, kinship reduplicate allows retriplication when stretched to the third generation. The paper concludes by calling for more study on retriplication in other languages of the world, particularly, African and Asian languages that massively exhibit the two phenomena.
\end{abstract}

Article information Received: 29 October 2020

Keywords: Morphological process; Reduplication; Retriplication; the Yoruba language

\section{Introduction}

The Yoruba language, a regional code with speakers from within and outside
Nigeria, belongs to Kwa sub-family of African languages. Its study, which began in the late $19^{\text {th }}$ century among the free slaves in Liberia and Sierra-Leone, has increased in magnitude, 
reflecting in almost all areas of its linguistics; phonetics, phonology, morphology, syntax, semantics, pragmatics, etc (Pulleyblank, 2009). Morphology, as the study of the ways words are formed in languages, is characterised by word formation processes of compounding, refashioning, blending, clipping, reduplication, acronymy, and so on (Haspelmath and Sims, 2010). Of all these processes, reduplication has generated tremendous interest among scholars more than all the other processes put together (Inkelas \& Downing, 2015).

That the study of reduplication has attracted robust scholarly attention may be a proof of its massive productivity in many languages of the world. According to The World Atlas of Language Structure Online (2013), Rubino's survey of reduplication reveals that $85 \%$ of the 368 languages investigated attest the feature of reduplication. The Atlas further shows that of the 368 languages surveyed, 277 (89\%) reflect both full and partial reduplication, while 35 languages (11\%) exhibit only full reduplication (Inkelas, 2013, p.1).

As touching the definitions, features and functions of reduplication in some world languages, it should be stressed again that reduplication is one of the most popularly constructed phenomena in languages of the world. Abakah (2015), Urbanczyk (2017) and Taiwo (2017) are unanimous in their definition of reduplication. They define it as a word formation process in which meaning is expressed by repeating all or part of a word. Similarly, Collins English Dictionary online (2009) describes it as the process, or an instance of redoubling meaning or pronunciation. However, Inkelas (2013, p.1) discusses it from the different morphological functions, occurring "at many points on a spectrum from phonologically defined partial reduplication to the repetition of syntactic phrases."

Furthermore, Xu (2016) reveals that the study of reduplications assumes high dimensions in the $70 \mathrm{~s}$, while stressing that recent study even indicates that child and sign languages exhibit reduplication. He discloses that Asian languages including Indonesian,
Modern Hindi, Japanese and other languages, belonging to different language families of Sino-Tibetan, Altaic, Miao-Yao and Tai, as well as most African languages reflect reduplication. $\mathrm{Xu}$ then describes the features and functions of reduplication across some world languages in terms of totality, plurality, distribution and expression of intensification. However, Yoruba, an African language, the focus of this paper, has also been explored along this line.

The Yoruba Language exhibits many of the morphological processes, thereby engaging the attention of some scholars in Yoruba linguistics (Awoyale, 1989; Tinuoye 1991; Ola, 1995; Awobuluyi, 2000; Taiwo 2011 and Taiwo, 2014). In the language, reduplication and retriplication (a novel concept introduced in this paper reflecting the triple copying of a morpheme root, stem or base in discourse) have prominent usage. While exploring reduplication features in Yoruba, Awoyale (1989) shows the profound productivity of full and partial reduplication with great emphasis on its types and functions. In a similar vein, Awobuluyi (2000) explores the taxonomy of morphological reduplication in Yoruba by listing the formation processes of both full and partial reduplication. But Taiwo (2011, 2013) approach the Yoruba morphology from the syntactic point of view. According to Taiwo, (2017), the preponderant attestation of reduplication process in Yoruba makes the language highly significant in the comity of reduplication languages of the world. Interestingly, the research of Pulleyblank (2009) on Yoruba reduplication makes a comprehensive study by drawing inferences from the works of Kiyomi (1985); Awoyale, (1989), Ola (1995), Inkelas (2013) and others. He identifies different classes of reduplication in Yoruba, such as agentive reduplication, infixing reduplication, distributive reduplication and gerundive reduplication.

It should be stressed at this juncture that the morphological process of copying the root, stem or base word in a language can transcend reduplication. Put in a different way, the process of reduplication can extend and culminate in triplication, denoting the nominalisation of an agent, or depicting the 
continuation or intensification of action in many languages. According to Moravcsik (1978, p. 88), in Pingelapese, a Micronesian language which belongs to the federated state of Micronesia, triplication is a productive phenomenon. Triplication usage in the language shows that an action is continuous or still happening. For example, in Pingelapese, we have wou (to bark), wouwou(barking), wouwouwou (still barking); pap (to swim), pahpap (swimming) pahpahpap (still swimming). In many African and Asian languages, the prominence of triplication is as evident as reduplication (Ghomeshi et.al, 2004; Zeitoun, 2007).

According to Nadaraja (2006), in English language, tripilication can also be observed, noting that, however, this feature in English language is but more of an exception. She gives some examples such as win, win, win; you, you, you; and tic, tac, toe, (p. 41). However, in this paper, the term "retriplication", an extension of reduplication, is adopted to represent the feature so as to conform to the euphony of its shoot, "reduplication". In other words, the adoption of the term "retriplication" is largely in tandem with the phonological and morphological prefix of its antecedent, "reduplication". This, therefore, is to imply that if the doubling of a root, stem or a word is referred to as "reduplication," the tripling of such of a word, stem or part of the word could also be referred to as "retriplication", by prefixing the "re-" to "triplication".

In fact, little or no work has been done on "retriplication". As already noted, Moravcsik (1978) only discusses in passing the phenomenon of triplication (referred to here as retriplication) in some languages. They are Mokilese and Pingalapese which are Micronesian languages and Telugu, a South Asian language. Also, Ikeokwu (2002) studies the phenomenon of reduplication in Bokyi, a language spoken in Cross River State of Nigeria. She extended in passing her discovery to the phenomenon of the triple copying of the root stem or base lexicon in Bokyi language.
In essence, what can be said about reduplication in the literature cannot be said about retriplication because the volume of research or exploration on reduplication worldwide is unprecedented. But as productive as the process of retriplication is in the Yoruba and many other African languages, it is grossly unexplored. In this paper, therefore, the study of retriplication alongside reduplication deserves our full attention because of its novelty. While this study is not just set out to explore the concept of retriplication as a morphological process that transcends the process of reduplication, it stands to explore the feature of Yoruba retriplication as a process that makes use of reduplication as the springboard of its operation. By implication, reduplication is considered in this article as a precursor to retriplication. Hence, the data reflecting the two concepts are presented for analysis.

\section{Methodology}

The data for this study were collected from diverse sources using the standard Yoruba as the benchmark. The researcher explored both formal and informal sources using six well instructed research assistants in addition. The research assistants were teachers, but students of the researcher in part-time Sandwich Program (one each in Lagos, Ibadan, Oshogbo, Abeokuta, Ondo and Ado Ekiti), covering all the Yoruba-speaking states in South-West Nigeria. The researcher however elicited data from Ilorin, another Yoruba-speaking metropolis in the North Central Zone of Nigeria. As part-time students, the research assistants were useful because they resided in those locations and there were contacts and coordination between July and September each year for the period of their study. They were trained on how to collect data from both informal and formal sources, especially through live conversations.

The researcher and research assistants made several visits to schools, market places, shopping malls, churches and public occasions in the Yoruba speaking cities mentioned above. A huge number of data were collected through which the data for analysis were randomly selected. As a native 
speaker of the language, the researcher personally made a close study of the data and sifted out the Yoruba nouns, verbs, adverbs and adjectives from which most of the reduplicated and retriplicated linguistic elements were derived. The data collected contained lexical categories or word classes that lend themselves to reduplicative and retriplicative analysis. In other words, the lexical items and phrases that can be processed into retriplication as an extension of reduplication form the focus of selection for analysis.

In analysing the data, Pulleyblank's (2009) approach of taxonomising the base morphemes alongside their reduplicative forms is applied. A close study of all the data reveals that all the reduplicative and retriplicative morphemes have consonant initials. Hence, all Yoruba consonant alphabetical order was. used for the organisation of all possible base forms that could be reduplicated and retriplicated. However, the researcher added the idea of presenting some of the live utterances elicited during partiipant observations, containing the use of retriplication for the purpose of exemplification.

\section{Results and Discussion}

In this section, the data elucidated for the investigation of reduplication and retriplication as observed in the Yoruba language are presented, analysed and discussed. The approach adopted for the analysis is the taxonomising model of Pulleyblank (2009). Consequent upon this, three forms of reduplication and retriplication are identified and explored. The first type, (Tables 1-8 and 10), are those that express intensification or emphasis at the level of reduplication on the one hand, and great intensification or emphasis at the level of retriplication on the other hand; the second, (Table 9), represents adjectivised comparative reduplication and superlative retriplication. In other words, the base words in this table are adjectives that exhibit attribute or quality at the level of reduplication, and at retriplication express great quality in superlation. The third, (Table 11) reflects the descent or ascent family relationship at reduplication and long descent or ascent at retriplicative continuum of nominal kinship. Importantly also, some sentences depicting the usage of retriplication at the domains of home, slaughter slab, farm, market, relaxation centre, community meeting place, plastic reparing/sealing centre, and in others are illustrated.

It is further discovered and demonstrated in this study that reduplication and retriplication can also operate at phrasal level, and specifically, some Yoruba verb phrases are retriplicated. It also comes to the limelight that all cases of retriplication are a resultant function of reduplication, but not the vice-versa. In other words, while all instances of retriplicationevolve from the reduplication process, not all cases of reduplication culminate in retriplication. This is exemplified in Table 12, while all the tables are explicated as follows.

Table1: Intensification

\begin{tabular}{|l|l|l|l|l|l|l|}
\hline & Base & \multicolumn{1}{|c|}{ Gloss } & Reduplication & \multicolumn{1}{|c|}{ Gloss } & Retriplication & \multicolumn{1}{|c|}{ Gloss } \\
\hline a. & bé & hops & Bé bé & hops more & bé bé bé & hops more and more \\
\hline b. & bí & give birth & bí bí & gives birth more & bí bí bí & $\begin{array}{l}\text { gives birth more and } \\
\text { more }\end{array}$ \\
\hline c. & bó & remove & bó bó & removes more & bó bó bó & removes more and more \\
\hline d. & bẹ & peels & bẹ bẹ & peels more & bẹ bẹ bẹ & peels more and more \\
\hline
\end{tabular}

Our findings from the table above shows that in (1a), the verb bé (hop) becomes bé bé at reduplication for intensification or emphasis, and becomes bé bé bé at retriplication for great intensification or emphasis. Similarly, the words bí-(1b), bó-(1c) be-(1d), are reduplicated for intensification and retriplicated for great 
intensification or emphasis. Furthermore, in table (1a-d) the tone of the base verbs are reduplicated and retriplicated in totality. Let us see the examples of their usage as bserved in some Yoruba contexts of conversation.

a. Àkèré nán àn bé bé bé kó tó kú toad the hop hop hop That it before die "The toad hopped greatly or seriously before it died"

b. Abiyamo ni ewúre yen ó bí bí bí productive mother is goat that it give birth give birth give birth "That goat is very productive in motherhood, it gave birth several times"

c. Ege ti a bó Bó bó cassava tuber pieces that we remove the back remove the back remove the back

$\begin{array}{llll}\text { yen } & \text { ti } & \text { po } & \text { jù } \\ \text { that } & \text { has } & \text { plenty }\end{array}$

"The soaked pieces of cassava tuber whose backs we removed and removed were too plenty"

d. Isu yen ti po jù a be be be sùgbón a yam that has plenty more we peel peel peel but we

kò lè parí ẹ

not able finish it

"The yam tubers are plenty, we peeled and peeled, but could not finish them"

From the contexts of usage above, retriplication in Sentences (a and $c$ ) is accomplished for intensification or emphasis in the farm, while retriplication in Sentences (b and d) is realised for great intensification or emphasis at home.

Table 2: Intesification

\begin{tabular}{|c|l|l|l|l|l|l|}
\hline & Base & \multicolumn{1}{c|}{ Gloss } & Reduplication & \multicolumn{1}{c|}{ Gloss } & Retriplication & \multicolumn{1}{c|}{ Gloss } \\
\hline a. & dí & block & dí dí & block more & dí dí dí & block more and more \\
\hline b. & dú & slaughter & dú dú & slaughter more & dú dú dú & slaughter more and more \\
\hline c. & dúró & wait & dúró dúró & wait more & dúró dúró dúró & wait more and more \\
\hline d. & dà & spill & dada & spills more & dà dà dà & spills more and more \\
\hline
\end{tabular}

In Table (2a), dí (block) is intensified or emphasised to have dí dí as its reduplicative form, while it is intensified in a great way to have it as dí dí dí in its retriplicative form. Likewise, (2b)-dú (slaughter); (2c)-dúró (wait); and (2d)-dà (spill) respectively become reduplicated in the fourth column for intensification or emphasis, and retriplicated in the sixth column for great intensification or emphasis. The examples of the retriplicated verbs above as used in Yoruba contexts are as follows:
a. Awọn ike yẹn n those plastic ones +press
jò lónà tó leak way that is
pọ; a
many we 
dí dí dí ó sú wa

block block block it tire us

"Those plastic containers were leaking in many parts; we blocked and blocked them; we were tired."

$\begin{array}{lllllll}\text { b. Wọn } & \text { dú } & \text { mààlúù } & \text { tó } & \text { po, wón dú } & \text { dú } \\ \text { they } & \text { slaughter } & \text { cow } & \text { That is } & \text { plenty they slaughter } & \text { slaughter }\end{array}$

$\begin{array}{lllll}\text { dú } & \text { títí } & \text { ojú } & \text { fi } & \text { sú } \\ \text { slaughter } & \text { till } & \text { eye } & \text { become } & \text { dark }\end{array}$

"They slaughtered many cows; they slaughtered and slaughtered until it was dark"

c. A dúró dúró dúró Sùgbón wọn òn wá.

We wait wait Wait but they not come

"We waited and waited, but they did not come"

d. Èjẹ dà dà dà lara obìnrin yẹn ní gbà

blood spill spill spill atbody woman that at when

tó bímọ tán.

That she give birth finish

"That woman bled and bled greatly after being delivered of a baby"

As used above, retriplication functions for great intensification or emphasis in Sentence (a) at the plastic sealing centre; in sentence (b) at the slaughter slab; in Sentence (c) at the community meeting place; and in Sentence (d) at the maternity wing of a hospital.

Table 3: Intensification

\begin{tabular}{|l|l|l|l|l|l|l|}
\hline & Base & \multicolumn{1}{c|}{ Gloss } & Reduplication & \multicolumn{1}{c|}{ Gloss } & Retriplication & \multicolumn{1}{c|}{ Gloss } \\
\hline a. & fò & Jump & fò fò & jumps more & fò fò fò & jumps more and more \\
\hline b. & fé & Blow & fé fé & blow more & fé fé fé & blowmore and more \\
\hline c. & fó & Break & fó fó & break more & fó fó fó & break more and more \\
\hline d. & fún & spin & fún fún & spin more & fún fún f'un & spin more and more \\
\hline
\end{tabular}

Table (3a-d) reveals there duplication of the base verbs in the second column in the fourth column, while they are retriplicated in the sixth column.This implies that fò jump-(3a); fé blow-(3b); fó break-(3c); and fún spin-(3d), are all reduplicated for intensification or emphasis in the fourth column, while they are being retriplicated in colum six for great intensification or emphasis.
a. A fò
fò fò
fò kí tó

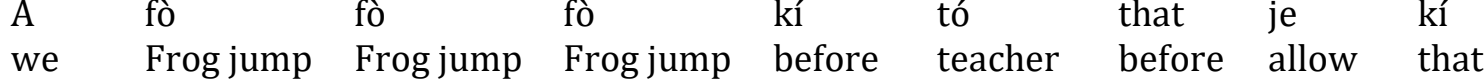
that je
we Frog jump Frog jump Frog jump before teacher before allow that
kí

$\begin{array}{lll}\text { a } & \text { wọ } & \text { kíláàsì } \\ \text { we } & \text { enter } & \text { class }\end{array}$
"We frog-jumped several times before the teacher could allow us to enter the class" 
b. Iná yẹn ò tètè jò; a fé ẹ fé ẹ fé ẹ fire that no quick glow we blow it blow it blow it "The flame did not kindle quickly; we blew it several times"

c. Won sisẹ ní bi àpáta yen wón fọ $\quad$ o fọ $\quad 09$ fọ $\quad$ ọ they dowork at place rock that they break it break it break it "They did a lot on that rock; they broke it several or many times"

d. Asọ yẹn ti tóbi jù; wọn Fún un, fún un, fún un, cloth that has large more they spin it spin it spin It

wọn òn rí i fún

they not see it Spin

"The cloth is too large; they attempted spinning and spinning it; they couldn't"

In Sentences (a-d) above, it is discovered that retriplication, reflecting intensification operates in different contexts such as, at school-Sentence (a); at home-Sentence (b); at the relaxation centre-Sentence (c); and at home where washing of cloths is taking place-Sentence (d). It also comes to the limelight that in Table 3, Sentences (b-d), the utterances exhibit phrasal retriplication in the form of $\mathrm{V}+\mathrm{NP}$ syntagm:

Table 4: Intensification and Degree of Quality

\begin{tabular}{|l|l|l|l|l|l|l|}
\hline & Base & \multicolumn{1}{|c|}{ Gloss } & Reduplication & \multicolumn{1}{c|}{ Gloss } & Retriplication & \multicolumn{1}{c|}{ Gloss } \\
\hline a. & gún & pound & gún gún & pound more & gún gún gún & poundmore and more \\
\hline b. & gé & cut & ge gé & cut more & gé gé gé & cut more and more \\
\hline c. & ga & tall & ga ga & Tallmore & ga ga ga & tall more and more \\
\hline
\end{tabular}

In the table above, (4a and b) (Column 2) are base verbs, while (4c) is a base adjective. While the base verbs are reduplicated at column four to show intensification of actions, they are retriplicated at column six to show great intensification of actions. However, the reduplication of $g a$ (tall) in (4c)-ga ga shows a degree of height of something, while its retriplicative form in column six-ga ga ga reflects a great or high degree of height. Let us see their usage in Yoruba contexts:

a. Won gún yán, gún yán gún yán síbè iyán yẹn ò They pound yam Pound yam pund yam still pounded that not

ká rí awọn àlejò.

go round those visitor

"They pounded and pounded much yam, but the food could not go round the visitors"

b. Igi tí wọn gé gé gé tí kò se é gé ni tree that they cut cut cut that not do it cut Is

aféfe nlá ti wó lulè

wind wild has fall At down

"The tree that was too difficult to cut, has fallen under the wild wind" 
$\begin{array}{lllllllll}\text { c. Ope } & \text { kan } & \text { ò } & \text { lè } & \text { ga ga ga } & \text { gá } & \text { kàn'run. } \\ & \text { Palm tree } & \text { one } & \text { not } & \text { can tall tall tall } & \text { that } & \text { reach heaven }\end{array}$

"A palm tree cannot be so tall to reach the heaven"

In the sentences above, it is discovered that the retriplication of intensification is realised at a naming ceremony-Sentence (a); in the farm-Sentence (b); and during a discussion between friends-Sentence(c). Furthermore, our findings show that the retriplication in
Sentence 4(a) (gún yán: pound yam) reflects the syntagm of V+NP (gún +yán: pound + yam). But sentence (4c) depicts a proverbial degree of quality.

Table 5: Intensification

\begin{tabular}{|l|l|l|l|l|l|l|}
\hline & Base & \multicolumn{1}{|c|}{ Gloss } & Reduplication & \multicolumn{1}{c|}{ Gloss } & \multicolumn{1}{c|}{ Retriplication } & \multicolumn{1}{c|}{ Gloss } \\
\hline a. & gbá & play (of football) & gbá gbá & play more & gbá gbá gbá & playmore and more \\
\hline b. & gbé & lift up & gbé gbé & lift more & gbé gbé gbé & liftup more and more \\
\hline c. & gbòn & shake & gbòn gbòn & shakemore & gbòn gbòn gbòn & shake more and more \\
\hline
\end{tabular}

Table 5 above also depicts the reduplication and retrplication of base verbs. For instance, (5a)-gbá (Second column) is reduplicated in the fourth column to become gbá gbá and retriplicated in column six as gbá gbá gbá. While the reduplicated form implies an intensity of football playing, its retriplicative counterpart depicts a great intensity of soccer. Similarly, (5b) gbé-lift up and $(5 c)$ gbòn-shake are reduplicated at column four and retriplicated in column six to show great and great intensification of actions, respectively. Usage in contexts:

\section{a. A gbá gbá gbá síbẹ wọn nàn wá we play play play still they beat us "We played, played and played, yet they beat us"}

b. Eru yen wuwo mo gbé e gbé e gbé mi ì ri i gbé load that heavy I lift it lift it lift I not see it lift "That load is heavy, I tried hard but I couldn't lift it up"

c. Ó gbòn gbòn gbòn ní wájú ògá rè; kò rí nkankan wí he shake shake shale At front master his he not see anything say "He was shook and shook seriously before his master; he had nothing to say"

Sentence (5a) represents a retriplicated use of the word gbá (play football) in an action that took place on a soccer field, while sentence (5b) refers to another retriplication used in the farm where the speaker is informing his father on the heaviness of the load he (the speaker) is to carry home. The retriplication in Sentence (5c) refers to the great intensity of the physical shaking of a trainee before her master out of fear on an offence he committed. In essence, great intensification of actions in the discourse underscores retriplication.

Table 6: Intensification

\begin{tabular}{|l|l|l|l|l|l|l|}
\hline & Base & \multicolumn{1}{|c|}{ Gloss } & Reduplication & \multicolumn{1}{c|}{ Gloss } & Retriplication & \multicolumn{1}{c|}{ Gloss } \\
\hline a. & ha & threat & ha ha & threat more & ha ha ha & threat more and more \\
\hline
\end{tabular}




\begin{tabular}{|l|l|l|l|l|l|l|}
\hline b. & hu & sob & hu hu & sob more & hu hu hu & sob more and more \\
\hline c. & hó & boil & hó hó & boil more & hó hó hó & boil more and more \\
\hline
\end{tabular}

It is discovered that the base verbs, ha-threat (6a); hu-sob (6b); and hó-boil (6c), are all reduplicated in column four and retriplicated in column six. For instance, $h a$-threat (6a) is reduplicated as $h a h a$, and is retriplicated as ha ha $h a$, while $h u-s o b(6 \mathrm{~b})$, is reduplicated as $h u h u$, and is retriplicated as hu hu hu. Similarly, hó-boil (6c), is reduplicated as hó hó, and retriplicated as hó hó hó. As in previous findings, all cases of reduplication are for intensification, while those of retriplication are for great intensification or emphasis. Their usage in contexts:

$\begin{array}{llllllll}\text { a. Ile ló } & \text { ha ha ha títí } & \text { wọn } & \text { fi } & \text { lù } & \text { bolẹ } \\ & \text { ground is } & \text { threat threat threat till } & \text { they } & \text { use } & \text { beat At ground }\end{array}$ "It was threat that he was seriously issuing and issuing, till they beat him hands down"

b. $0 \mathrm{hu}$ hu hu nígbà tó gbọ kú ọá ẹ he sob sob sob when he hear death boss his "He seriously sobs and sobs when he heard about the death of his boss"

c. Omi yen hó hó hó títí tó fi gbẹ tán water that boil boil boil till it use dry up "The water seriously boiled and boiled until it dried up"

Sentence (6a) is used in an interaction between some discussants who are referring to a boxing bout where the challenger of the contest was beaten hands down despite his boastings before the duel. Sentence (6b) reflects the use of retriplication at a forum where an apprentice goes down in tears on hearing about the demise of his trainer, while Sentence (6c) indicates the use of retriplication at home, especially, about an event in the kitchen. All the usages of retriplication above represent great intensification or emphasis.

Table 7: Intensification

\begin{tabular}{|l|l|l|l|l|l|l|}
\hline & Base & Gloss & Reduplication & \multicolumn{1}{c|}{ Gloss } & Retriplication & \multicolumn{1}{c|}{ Gloss } \\
\hline a. & jà & fight & ja jà & fight more & ja ja ja & fight more and more \\
\hline b. & jù & throw & ju ju & throw more & jù jù jù & throw more and more \\
\hline c. & jẹ & eat & jẹ jẹ & eat more & jẹ jẹ jẹ & eat more and more \\
\hline d. & jó & dance & jó jó & dance more & jó jó jó & dance more and more \\
\hline
\end{tabular}

From the table above, base verbs in column two are reduplicated in column four and retriplicated in column six. For instance, (7a) jà-fight; (7b) jù-throw; (7c) jẹ-eat; (7d) jó-dance; are all reduplicated in column four for intensification or emphasis, while they are all retriplicated in column six for great intensification or emphasis. Usage in context:

a. Olúwa ti fi iná jó ogun tí a jà jà jà tí kò sé Lord has use fire burn battle that we fight fight fight that not cease "The Lord has devoured the battle that we greatly fought and fought, which refused to cease" 
b. Òkò ló jù jù jù loju ona titi ó fi Sè se stone is he throw throw Throw At eye way till he use sustain injury "It was stone that he seriously threw and threw on the way till he sustained an injury"

c. Wọmbìa giliti! 0 jẹ jẹjẹ kò yó glutton wanton he eat eat eat not Fill/satisfied "A wanton glutton! He ate and ate seriously without becoming filled/satified".

d. Ni ibi igbeyawo omo è ó jó jó jó afi bi kòkòrò! at place wedding son his he dance dance dance as like insect "At the ceremony of his son, he danced and danced seriously like an insect"

The use of jà jà jà in Sentence (7a) reflects the feature ofretriplication at a prayer

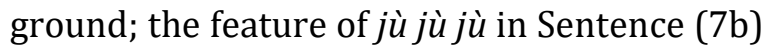
indicates the use of retriplication on the way to somewhere; the use of je je je in Sentence (7c) reveals the feature of retriplication at home; and the use of jo jó jó in Sentence (7d) represents the use of retriplication at a wedding ceremony.

Table 8: Intensification

\begin{tabular}{|l|l|l|l|l|l|l|}
\hline & Base & \multicolumn{1}{|c|}{ Gloss } & Reduplication & \multicolumn{1}{c|}{ Gloss } & Retriplication & \multicolumn{1}{c|}{ Gloss } \\
\hline a. & kà & count & kà kà & count more & ka ka kà & count more and more \\
\hline b. & ké & cry & ké ké ké & cry more & ké ké ké & cry more and more \\
\hline c. & kù & thunder & kù kù & thunder more & ku ku kù & thunder more and more \\
\hline
\end{tabular}

As in the previous tables, the base verbs in Table 8, column two, are reduplicated in column four and retriplicated in column six. For example, (8a) kà count; (8b) ké cry; and kù thunder; are all reduplicated in column four for intensification or emphasis, and retriplicated in column six for great intensification or emphasis. Let us see their usage in the Yoruba contexts.

$\begin{array}{llllllll}\text { a. Ebè } & \text { tán } & \text { ní } & \text { ká } & \text { wá } & \text { kà } & \text { rújú; } & \text { a } \\ \text { heap } & \text { That they } & \text { say } & \text { That we } & \text { come } & \text { count } & \text { confuse eye } & \text { we }\end{array}$

kà kà kà ó sú wa

count count count it tire us

"The heaps (in the farm) that we were invited to count were confusing; we seriously counted and counted; we were tired"

b. Omọ náàn ké ké ké kí mòmó rè tó dé Child the cry cry cry before mother it does arrive "The child cried greatly before his mother arrived"

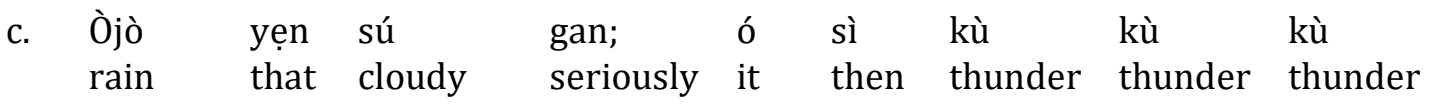

sùgbón kò rọ

but not fall

"That rainseriously thundered and thundered, but did not fall" 
The retriplication in Sentences (8a) kà kà kà, is an action that takes place in the farm; while Sentence $(8 \mathrm{~b})$ ké ké ké, and $(8 \mathrm{c})$ kù kù kù are referring to actions that take place at home. In table 9 below, the reduplicated adjectives in column four are in comparative structure, while the retriplicated forms in column six are in superlative structure.

Table 9: Adjectivisation by Reduplication and Retriplication

\begin{tabular}{|l|l|l|l|l|l|l|}
\hline & Base & Gloss & Reduplication & \multicolumn{1}{|c|}{ Gloss } & Retriplication & \multicolumn{1}{c|}{ Gloss } \\
\hline a. & Le & hard & le le & very hard & le le le & very very hard \\
\hline b. & gùn & long & gùn gùn & very long & gùn gùn gùn & very very long \\
\hline c. & kúrú & short & kúrú kúrú & very short & kúrú kúrú kúrú & very very long \\
\hline d. & Fè & Wide & fè fè & very wide & fè fè fè & very very wide \\
\hline
\end{tabular}

Table 10: Intensification of Adverbs by Reduplication and Retriplication

\begin{tabular}{|l|l|l|l|l|l|l|}
\hline & Base & \multicolumn{1}{|c|}{ Gloss } & Reduplication & \multicolumn{1}{c|}{ Gloss } & \multicolumn{1}{c|}{ Retriplication } & \multicolumn{1}{c|}{ Gloss } \\
\hline a. & kíá & quickly & kíá kíá & very quickly & kíá kíá kíá & very very quickly \\
\hline b. & kánmó & fastly & kánmó kánmó & very fastly & kánmó kànmò kánmó & very veryfastly \\
\hline c. & jéjé & fastly & jéjé jéjé & very gently & jeje jeje jeje & very very gently \\
\hline d. & díẹ & little & díe díẹ & very little & díẹ díe díe & very very little \\
\hline
\end{tabular}

Table 11: Kinship Nominals by Reduplication and Retriplication

\begin{tabular}{|l|l|l|l|l|l|l|}
\hline & Base & Gloss & Reduplication & \multicolumn{1}{c|}{ Gloss } & \multicolumn{1}{c|}{ Retriplication } & \multicolumn{1}{c|}{ Gloss } \\
\hline a. & ọmọ & child & ọmọ ọmọ & grand child & ọmọ ọmọ ọmọ & great grand child \\
\hline b. & ìyá & mother & iyá ìyá & grand mother & ìyá ìyá ìyá & great grand mother \\
\hline c. & bàbá & father & bàbá bàbá & grand father & bàbá bàbá bàbá & great grand father \\
\hline
\end{tabular}

Table 10 contains adverbs which are reduplicated for intensification in column four and retriplicated for great intensification in column six. Table 11 reflects kinship terms in the Yoruba language. The language makes use of reduplication and retriplication for expression of kinship line in family descent or ascent to the third generation.

\section{Reduplication Versus Retriplication}

It has been revealed from Table 11 that reduplication by extension yields retriplication in thenominalisation process. However, it should be stressed that some reduplication depicting nominalisation in the Yoruba language cannot culminate in retriplication. Let us see the table 12

\section{Table 12: Reduplication without Retriplication}

\begin{tabular}{|l|l|l|l|l|l|}
\hline & Base & \multicolumn{1}{|c|}{ Gloss } & Reduplication & \multicolumn{1}{|c|}{ Gloss } & Unacceptable Retriplication \\
\hline a. & paná & quench fire & paná paná & fire quencher & *pana pana pana \\
\hline b. & wole & inspect house & wole wole & health inspector & *wole wole wole \\
\hline c. & jaja & eat dog meat & jaja jaja & dog meat eater & * jaja jaja jaja \\
\hline d. & jeyin & tooth eater & Jeyin jeyin & tooth infection & *jeyin jeyin jeyin \\
\hline
\end{tabular}


Note: All the asterisked retriplicated forms are not accepted in the language. However, their verb form can be retriplicated to yield great intensification or emphasis. Importantly too, the fact that tables 1-12 contain reduplicated and retriplicated items confirms our earlier claim that the language has a robust feature of these processes, and this has afforded the speakers the competence of profuse and proficient use of reduplication and retriplication in discourse.

\section{Phrasal Retriplication}

Almost all the retriplicate verbs can be used in phrasal forms. For example, Table (1a), as in, bé (hop) can become bé mó mi (hop at me). The phrase can be retriplicated in discourse to become bé mó mi, be mo mi, bé mó mi (hopped at me, hopped at me and hopped at me) to depict great intensification and emphasis. Furthermore, Table (1b): bí (give birth to) can be phrased, as in, bímo, bímo ,bímo (give birth to, give birth to and give birth to). Similarly, Table (1c), bó (remove the back of something) can be retricatively phrased, as in, bó ege, bó ege, bó ege (remove cassava back, remove cassava back, remove cassava back). Likewise, Table (1d) be (peel) can also be used in a retriplicative phrase form, as in, be su, be su, be su (peel yam, peel yam, peel yam). AS earlier observed, these phrasal reduplication and retriplication can be structured in the syntagm of Verb+Noun, which can produce the notation $(\mathrm{V}+\mathrm{NP})$.

Although previous studies on retriplication are little or none, the study corroborates earlier studies on reduplication. For instance, the study confirms the findings of Moravcsik (1978), Tinuoye (1991), Ghomeshi et.al, (2004), Pulleyblank (2009), Inkelas (2013), and others, that reduplication functions mainly for intensification, emphasis, normalisatison and comparative degree. However, it needs to be reiterated that the findings that retriplication functions for great intensification or emphasis, for great kinship nominalisation and superlative degree is novel. It is also necessary to stress that all the retriplicative sentences given after each table are also constructible at reduplicative level, depending on the user's focus and the context. Furthermore, in Yoruba discourse, retriplication also performs rhetorical or musical function. On this, a particular Yoruba Christian song is exemplifying as follows:

\section{Chorus:}

Iná wá wá wá;

Fire come come come

"Fire come and come greatly"

Wá jo wọn run

come burn them consumptively

"Come to devour them!"

Ogun ti mo jà jà jà

battle that I fought fought fought

"The battle that I fought and fought"

Tí kò sé

that not cease

"That does not cease"

Iná wá wá wá;

fire come come come

"Fire come and come"

Wa jó wọn run come burn them consumptively

"Come to devour them consumptively"

In the chorus above, retriplication occurs in lines 1,3 and 5 .

\section{Conclusion}

In the literature, as noted earlier, the study of reduplication has singly occupied the center stage in phonological and morphological linguistic research. But the phenomenon of retriplication is startling and revealing. This feature in the Yoruba language is robustly enriching because it is profusely productive. This is not however to down-play the importance of reduplication process which has been found to be the springboard upon which the retriplication thrives. Reduplication (and retriplication), in the words of Nadarajan (2006, p. 40), are an "interesting word play which can serve to enrich any language". 
This study has not only presented and described the reduplicates and retriplicates of the base verbs, adjectives and adverbs, it has also demonstrated the usage of the retriplicants in contexts. Most of the sentences that follow the tables were observed in real life situations. As earlier said, the sentences exemplifying the base verbs in reduplication and retriplication were observed in different sociolinguistic domains, such as, the farm, home, market, motor park, worship centre and others. The study is a confirmation of the productivity and the robust features of reduplication and retriplication in the Yoruba language. More of this study should be replicated to reveal the productivity or otherwise of the feature of retriplication in other languages of the world.

\section{References}

Abakar, E. (2015). On Tone and Morphology of the Akan Reduplication Construction. Journal of Universal Languagge. 16(1), 1-47

Awobuluyi, O. (2000). Mofoloji ede Yoruba. In Bade A. (ed.), Ekó İjìnle Yoruba: Eda Ede, Litireso ati Asa (pp. 47-70). IjebuOde: Shebiotimo Press.

Awoyale, Y. (1989). Reduplication and the status of ideophones in Yoruba. Journal of West African Linguistics 2(3), 15-34.

Collins English Dictionary Online (2009).

Retrieved from https:// www.collinsdictionary.com

Gomesh, J. Jakendoff, R, Rosen,N.\&Russell, K. (2004). Contrastive focus: Reduplication in

Haspelmath, M. \& Sims, A. (2010). Understanding Morphology. London: Hodder Education https://doi.org/10.1093/acrefore/97 80/99384655.013.80
Ikeokwu, V. (2002). The Aspects of Bokyi Mophology (Undergraduate Thesis) University of Ilorin, Ilorin, Nigeria.

Inkelas, S. (2013). Handbook on Derivation. Published online. Retrieved from achive.org/stream/2013HandbookOf DerivationInkelas.reduplication

Inkelas, S. \& Downing L. (2015). What is reduplication? Typology and analysis part 1/2: Typology of reduplication. Language and Linguistics Compass 9(12) 502-515.

Kiyomi, S. (1995). A new approach to reduplication: a semantic study of noun and verb reduplication in Malayo-Polynessian languages. Linguistics (33) 1145-1167.

Moravcsik, E. (1978). Reduplicative Constructions. In J, Greenberg (ed.) Universals of Human Language: Word Structure. (pp. 297-354). Stanford: Stanford University Press.

Nadarajan, S. (2006).A crosslinguistic study of reduplication. (Uploaded paper) Retrieved from https://www.researchgate.net/public ation.

Ola, O. (1995). Vowel deletion in Yoruba verbnoun collocation revisited. Research in African Languages and Literatures (1), pp. 95-98.

Pulleybalnk, D. (2009). Patterns of Reduplication in Yoruba. In K. Hanson $\&$ S. Inkelas (eds.) The Nature of the Word: Essays in Honour of Paul Kiparsky, (pp 311-357). Cambridge, MA:MIT Press.

Rubino, C. (2013). In Dryer, M. S. \& Haapelmath, M (eds.) The World Atlass of Language Structures. Published Online. Leipzig Planck Institute for Evolutionary Anthropology. Retrieved from http:// www.wals.info/uthor/rubico 
Taiwo, E. (2017). Prosodic reduplication in Yoruba. Journal of Universal Language. 18(2) 39-59 Retrieved from Https//doi.org/10.2242

Taiwo, O. (2011). Mofoloji Ibadan: Unversal Akada Books Nigerian Limited.

Taiwo, 0. (2014). The morphosyntactic interaction and the derivation of nominal compounds in Yoruba. International Journal of Language Studies, 18(2) 39-59.

Tinuoye, M. (1991). A Comparative Analysis of English and Yoruba Morphology. Ibadan: Tafak Publication

Urbancyk, S. (2017). Phonological and Morphological Aspects of Reduplication. (Uploaded Paper) Retrieved from https://doi.org/10.1093/acrefore/97 80/99384655.013.80

Xu, D .(2016). Reduplication in languages: A case study of languages in China. Hal Archives-Ouvertes 42-63. Retrieved from https://hal.archivesouvertes.fr/hal-01386244

Zeitoun, E. (2007) La reduplication en rukaimantuaran. Faits de langues: Reduplication(2). 